\title{
Acute toxicity, lipid peroxidation and ameliorative properties of Alstonia boonei ethanol leaf extract on the kidney markers of alloxan induced diabetic rats
}

\author{
Enechi, O.C. ${ }^{*}$, Oluka, Ikenna H. and Ugwu, Okechukwu P.C. \\ Department of Biochemistry, University of Nigeria, Nsukka, Enugu State, Nigeria. \\ Accepted 20 January, 2014
}

\begin{abstract}
The lethal toxicity and lipid peroxidation studies of Alstonia boonei on alloxan induced diabetic rats were analysed. The effect of ethanol leaf extract of $A$. boonei on the kidney markers of diabetic rat was also determined. The acute toxicity of the ethanol extract of $A$. boonei was found to be more than 5000 $\mathrm{mg} / \mathrm{kg}$ body weight of the extract after $24 \mathrm{~h}$ of constant observation. The malondialdehyde concentration of the rats treated with 200 and $400 \mathrm{mg} / \mathrm{kg}$ body weights of the extract significantly decreased $(p<0.05)$ when compared with the untreated diabetic rats. There was no significant difference ( $p>0.05$ ) when malondialdehyde concentrations of rat treated with 200 and $400 \mathrm{mg} / \mathrm{kg}$ body weights of the extracts were compared with the standard control. But the creatinine concentration decreased significantly $(p<0.05)$ when 200 and $400 \mathrm{mg} / \mathrm{kg}$ body weights of the extract of the treated diabetic animals were compared with the diabetic control.
\end{abstract}

Key words: Alstonia boonei, diabetic rats, malondialdehyde, creatinine and urea.

\section{INTRODUCTION}

Diabetes mellitus represents a group of metabolic disorders in which there is an impaired glucose utilization inducing hyperglycemia which is an increase in the blood group level beyond normal values (Hazuda, 1991; Adonu et al., 2013). Diabetes is a chronic disease characterized by elevated blood glucose level and disturbances in carbohydrate, fat and protein metabolism (Sky, 2000; Rother, 2007; Andrew et al., 2013). In the local markets in West and Central Africa, Alstonia boonei is often among the most common sold plant as crude drugs. Parts of the plant are employed for the treatment of a variety of ailments in Africa and the stem bark has been listed in the Africa Pharmacopoeia as an antimalarial drug (Bello et al ., 2009).

$A$. boonei is a popular plant (Figure 1). It has many medicinal properties such as antifungal, antibacterial, anti-inflammatory, antiplasmodial, antimalarial, antipyretic, analgesic and hypotensive effects (Olajide et al., 2000). In this study, acute toxicity of $A$. boonei ethanol leaf extract and the effects of $A$. boonei ethanol leaf extract on the kidney markers and lipid peroxidation of diabetic rats were evaluated.

\section{MATERIALS AND METHODS}

Materials

Plant materials

Matured leaves of $A$. boonei were collected in Nsukka environs, Enugu State of Nigeria. The plants were identified and authenticcated by Mr. A. Ozioko of Bioresource Development and Conservation Programme (BDCP) Research Centre, Nsukka, where the voucher specimens were deposited in the herbarium of the Department of Botany, University of Nigeria, Nsukka. 


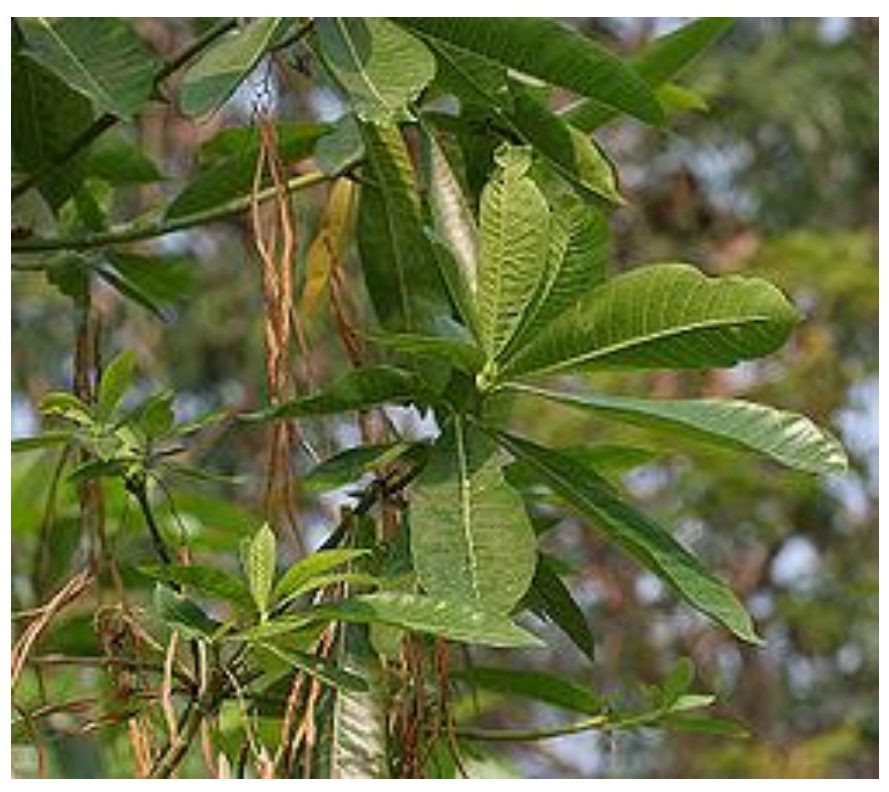

Figure 1. Pictorial view of Alstonia boonei leaves (Sidiyasa, 1998).

\section{Animals}

Adult Wistar albino rats of between 10 and 16 weeks with average weight of $160 \pm 13 \mathrm{~g}$ were obtained from the Animal House of the Faculty of Biological Sciences, University of Nigeria, Nsukka. The animals were acclimatised for 7 days under standard environmental conditions, with a $12 \mathrm{~h}$ light/dark cycle maintained on a regular feed (vital feed) and water ad libitum.

\section{Chemicals/reagents/samples}

All chemicals used in this study were of analytical grade and products of May and Baker, England; BDH, England and Merck, Darmstadt, Germany. Reagents used for all the assays were commercial kits and products of Randox, USA; Teco (TC), USA; Biosystem Reagents and Instruments, Spain; Glucose Analyzer, Accu Chek Active of Germany; alloxanmonohydrate, Sigma St. Louis, MO, USA.

\section{Instruments/equipment}

Water bath (Gallenkamp, England), Chemical Balance (Gallenkamp, England), Conical Flasks (Pyrex, England), Hotbox (Gallenkamp, England), Centrifuge (3,500 rpm, PIC, England), Digital Photo Calorimeter (El 312 Model, Japan), Adjustable Micropipette (Perfect, U.S.A.), Refrigerator (Kelvinator, Germany), pH Meter (Pye, Unicam 293, England), multi-well microtiter plate reader (Tecan, Austria), Glucose Analyzer, Accu Chek Active of Germany.

\section{Methods}

\section{Experimental protocol/design}

A total of twenty eight (28) albino Wistar rats were divided into seven (7) groups of four (4) rats each. The animals were grouped as follows: Group 1: (Reference/normal control): Rats were fed with normal diet and water ad libitum; Group 2: diabetic untreated rats (diabetic control); Group 3: rats were administered with $2 \mathrm{mg} / \mathrm{kg}$ b.w. of glibenclamide (standard drug/control); Group 4, diabetic rats were administered with low dose $(200 \mathrm{mg} / \mathrm{kg} \mathrm{b}$. w.) of the ethanol leaf extract of $A$. boonei; Group 5: diabetic rats were administered with high dose $(400 \mathrm{mg} / \mathrm{kg} \mathrm{b}$. w.) of the ethanol leaf extract of $A$. boonei; Group 6: normal rats were administered with low dose (200 $\mathrm{mg} / \mathrm{kg} \mathrm{b.} \mathrm{w.)} \mathrm{of} \mathrm{the} \mathrm{ethanol} \mathrm{leaf} \mathrm{extract} \mathrm{of} A$. boonei; Group 7: normal rats were administered with high dose $(400 \mathrm{mg} / \mathrm{kg} \mathrm{b}$. w.) of the ethanol leaf extract of $A$. boonei.

\section{Collection and preparation of extracts}

Matured leaves of $A$. boonei were obtained from the environs of Nsukka Local Government Area, of Enugu State of Nigeria. Specimens of these leaves were authenticated in the Department of Bioresource Development and Conservation Programme (BDCP) Research Centre, Nsukka, and voucher specimens deposited in the herbarium. Leaves of $A$. boonei were separately dried under shade for 7 days, and then pulverized into powder. A weight of $208.1 \mathrm{~g}$ of the sample (powder) was agitated in $70 \%$ ethanol organic solvent for $48 \mathrm{~h}$. The macerated extract was filtered with a cheese cloth and the filtrates concentrated in vacuo to $10 \%$ of the original volume at $40^{\circ} \mathrm{C}$. Concentrates were dried at $37^{\circ} \mathrm{C}$ to obtain percentage extract yield (35\%) of the crude extract from the leaves of $A$. boonei. The extracts were reconstituted prior to administration.

\section{Induction of experimental diabetes}

Diabetes was induced by intraperitoneal injection of $120 \mathrm{mg} / \mathrm{kg}$ body weight of alloxanmonohydrate (Sigma St. Louis, MO, USA) in overnight-fasted animals after acclimatization. Diabetes was confirmed five (5) to eight (8) days later in the alloxan-treated animals showing random blood glucose (RBG) level $\geq 200 \mathrm{mg} / \mathrm{dl}$ (11.1 $\mathrm{mmol} / \mathrm{L}$ ). Diabetes status determination was monitored on blood obtained from tail vein puncture using an automated glucose sensor machine GlucometerAnalyser (Accu Chek Active).

\section{Determination of extract yield}

The percentage yield of the ethanol extract of leaves of $A$. boonei was determined by weighing the pulverized leaf powder before extraction and the concentrated extract was obtained after extraction and then calculated using the formula:

Percentage yield $=\frac{\text { Weight of leaf powder }}{\text { Weight of extract }} \times 100$

\section{Toxicological studies}

\section{Acute toxicity and lethality $\left(L D_{50}\right)$ test}

Acute toxicity $\left(L_{50}\right)$ of the ethanol extract of $A$. boonei leaves were determined by Lorke's method (1983). A total of eighteen (18) adult albino mice were used for this investigation. The studies were conducted in two stages. In the first stage, three groups of three mice each were administered (p.o.) 10, 100, $1000 \mathrm{mg} / \mathrm{kg}$ body weight of the extract, respectively. The mice were observed for $24 \mathrm{~h}$ for a number of death and behavioural changes. In the second stage, based on the percentage survival rates, further increased doses of 1600,2900 and $5000 \mathrm{mg} / \mathrm{kg}$ body weight were administered (p.o.) to three additional mice for each group, respectively, and the fourth mice received only solvent (5\% Tween 80$)$ which served as the control. The mice were observed for $24 \mathrm{~h}$ and the number of deaths was recorded. The $\mathrm{LD}_{50}$ was calculated as the geo 
Table 1. The percentage yield of ethanol extract of Alstonia boonei leaves.

\begin{tabular}{ccc}
\hline Initial weight of ground leaf powder (g) & Final weight of extract (g) & Percentage (\%) \\
\hline 208.1 & 26.31 & 12.64 \\
\hline
\end{tabular}

Table 2. Results of the acute toxicity $\left(\mathrm{LD}_{50}\right)$ of the ethanol extract of Alstonia boonei leaves.

\begin{tabular}{ccc}
\hline Dose $(\mathbf{m g} / \mathbf{k g}$ body weight) & No. of animals before oral administration & No. of deaths after administration \\
\hline 10 & 3 & - \\
100 & 3 & - \\
1000 & 3 & - \\
1900 & 3 & - \\
2600 & 3 & - \\
5000 & 3 & - \\
\hline
\end{tabular}

geometric mean of the highest non-lethal and the lowest lethal doses.

\section{Determination of serum urea concentration}

The concentration of serum urea was determined using the method of Tietz (1994) as outlined in Randox kits, UK.

\section{Determination of serum creatinine concentration}

The concentration of serum creatinine was determined using the method of Tietz (1994) as outlined in Randox kits, UK.

\section{Determination of lipid peroxidation (malondialdehyde, MDA)}

The concentration of malondialdehyde was determined using the method of Draper and Hadley (1990).

\section{Statistical analysis}

Data were reported as means \pm SEM, where appropriate. Both oneand two-way analyses of variance (ANOVA) were used to analyse the experimental data and Duncan multiple test range was used to compare the group means obtained after each treatment with control measurements. Differences were considered significant when $\mathrm{p} \leq 0.05$.

\section{RESULTS}

\section{Percentage yield of the extract}

From the result in Table 1, the (\%) yield of the ethanol extract of $A$. boonei leaves was found to be $12.64 \%$.

\section{Acute toxicity studies of Alstonia boonei leaves}

The acute toxicity studies $\left(L_{50}\right)$ of the ethanol extract of $A$. boonei leaves showed that no animal died in any group after receiving increasing doses (between 10 and $5000 \mathrm{mg} / \mathrm{kg} \mathrm{b.w.)}$ of the ethanol extract of $A$. boonei leaves (Table 2).
Effects of the ethanol extract of Alstonia boonei leaves on urea concentration in normal and diabetic rats

Results in Figure 2 showed neither significant increase nor decrease $(p>0.05)$ in the urea concentration of the diabetic animals administered with $200 \mathrm{mg} / \mathrm{kg} \mathrm{b.w}$. of the extract compared with the normal control. Significantly elevated $(p<0.05)$ concentration of urea was observed in the $400 \mathrm{mg} / \mathrm{kg}$ b.w of extract treated diabetic rats compared with the normal control. The 200 and 400 $\mathrm{mg} / \mathrm{kg} \mathrm{b.w}$. of extract treated diabetic animals showed no significant increase or decrease $(p>0.05)$ compared to the diabetic control (group 2) as shown in Figure 2. The diabetic animals treated with low and high doses of the extract (200 and $400 \mathrm{mg} / \mathrm{kg}$ b.w.) showed significant decrease $(p<0.05)$ and increase $(p<0.05)$, respectively, compared with the diabetic animals treated with the standard drug. The normal animals administered low and high doses (200 and $400 \mathrm{mg} / \mathrm{kg}$ b.w.) of the extract showed no significant difference compared with the normal and diabetic controls (Groups 1 and 2) as shown in Figure 2. Interestingly, the $200 \mathrm{mg} / \mathrm{kg} \mathrm{b.w.} \mathrm{treated}$ normal animals showed a significant depreciation $(\mathrm{P}<0.05)$ in urea concentration compared with the glibenclamide-treated diabetic animals (standard control).

\section{Effects of ethanol extract of Alstonia Boonei leaves on creatinine concentration in normal and diabetic animals}

Creatinine concentration decreased significantly $(P<0.05)$ in the animals treated with low dose $(200 \mathrm{mg} / \mathrm{kg} \mathrm{b.w}$.) of the extract compared with the standard control as shown in Figure 3. There was no significant increase or decrease $(P>0.05)$ in the creatinine concentration of both the 200 and $400 \mathrm{mg} / \mathrm{kg} \mathrm{b.w}$. treated diabetic animals as compared with the diabetic control. There was, however, a significant increase $(p<0.05)$ in the creatinine concentra- 


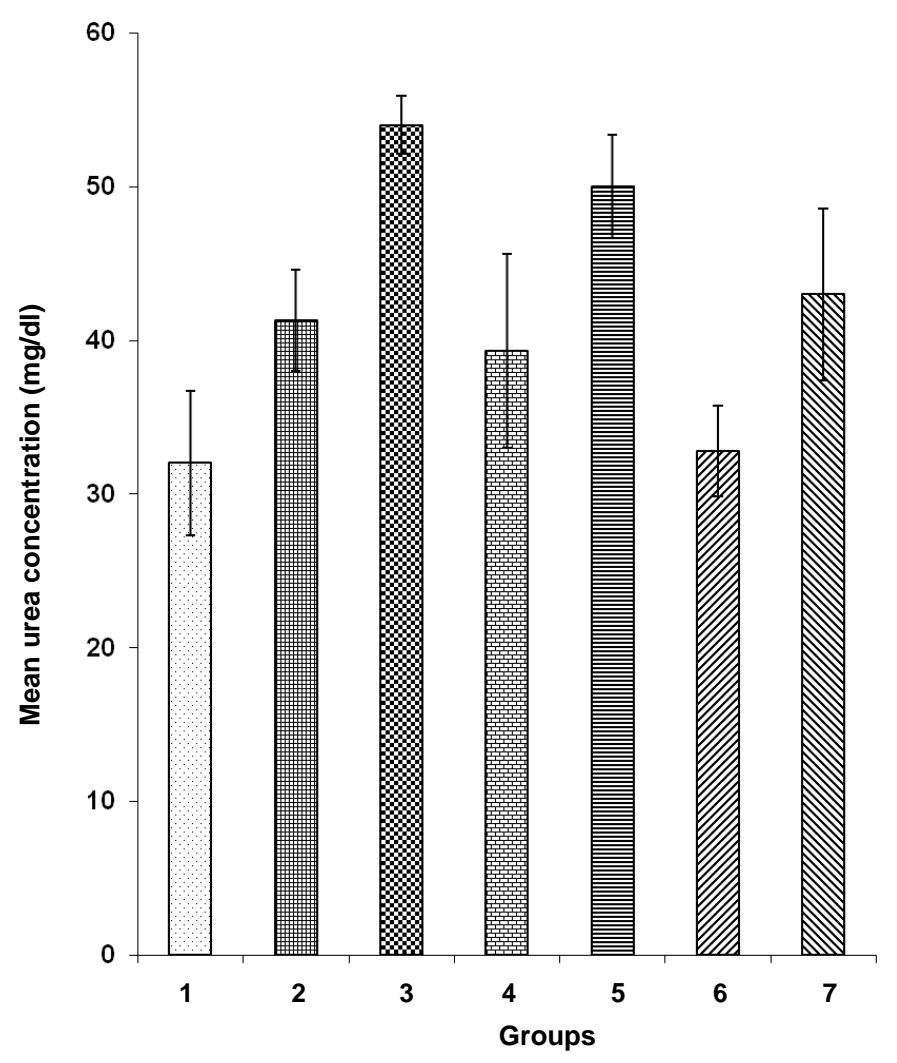

Figure 2. Effect of ethanol leaf extract of Alstonia boonei on the urea concentration of normal and diabetic rats. Group 1: Normal control; Group 2: diabetic control (Untreated); Group 3: diabetic + glibenclamide; Group 4: diabetic + $200 \mathrm{mg} / \mathrm{kg}$ of extract; Group 5: diabetic + $400 \mathrm{mg} / \mathrm{kg}$ of extract; Group 6: $200 \mathrm{mg} / \mathrm{kg}$ of extract; Group 7: $400 \mathrm{mg} / \mathrm{kg}$ of extract.

tion of the diabetic animals administered high dose (400 $\mathrm{mg} / \mathrm{kg} \mathrm{b.w.)} \mathrm{of} \mathrm{the} \mathrm{extract} \mathrm{compared} \mathrm{with} \mathrm{the} \mathrm{normal} \mathrm{con-}$ trol as shown in Figure 3.

\section{Effects of the ethanol extract of Alstonia Boonei leaves on malondialdehyde (MDA) concentration in normal and diabetic rats}

Observation carried out in Figure 4 reveals significant decrease $(p<0.05)$ in the MDA concentration of the diabetic rats treated with low and high $(200$ and $400 \mathrm{mg} / \mathrm{kg}$ b.w.) doses of the extract compared with the diabetic and control (Group 2). There was however no significant difference $(p>0.05)$ in the MDA concentration of these diabetic test animals (Groups 4 and 5) compared with the normal and standard controls. There was a significantly elevated $(p<0.05)$ concentration of MDA in the untreated diabetic rats (Group 2) compared with the rats administered with the standard drug. It is also pertinent to mention that the MDA concentration of the normal rats administered $400 \mathrm{mg} / \mathrm{kg}$ b.w. of the extract increased significantly $(p<0.05)$ compared with the normal and standard controls. The normal rats administered $400 \mathrm{mg} / \mathrm{kg}$ b.w. of

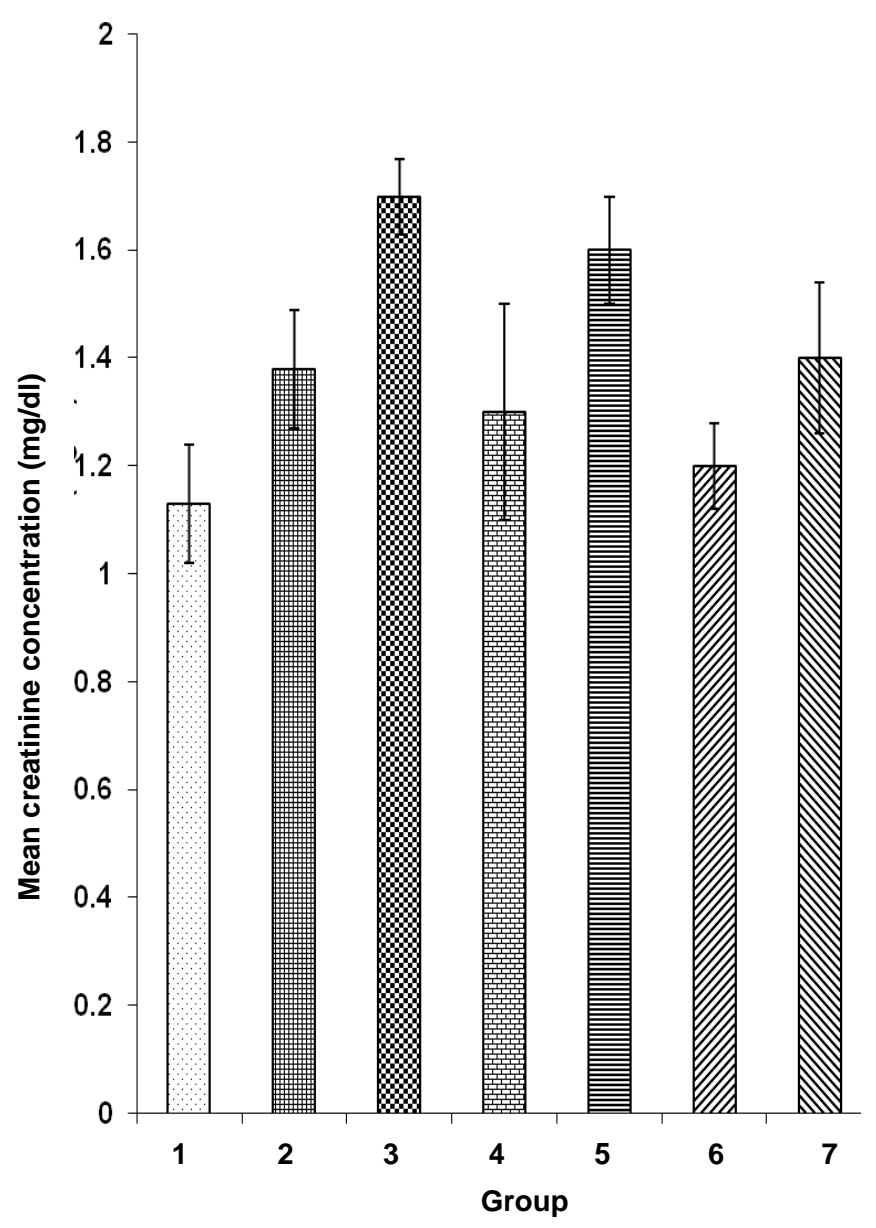

Figure 3. Effect of ethanol leaf extract of Alstonia boonei on the creatinine concentration of normal and diabetic rats. Group 1: Normal control; Group 2: diabetic control (untreated); Group 3: diabetic + glibenclamide; Group 4: diabetic $+200 \mathrm{mg} / \mathrm{kg}$ of extract; Group 5: diabetic + 400 mg/kg of extract; Group 6: 200 $\mathrm{mg} / \mathrm{kg}$ of extract; Group 7: $400 \mathrm{mg} / \mathrm{kg}$ of extract.

the extract also showed a significantly elevated $(p<0.05)$ MDA concentration compared with the diabetic rats treated with low and high doses of the extract, and the normal rats administered low dose $(200 \mathrm{mg} / \mathrm{kg})$ of the extract as shown in Figure 4.

\section{DISCUSSION}

Ayurvedic system of medicine relies on the administration of crude extract or concentration of crude extract of the plant material for the treatment of diabetes mellitus (Salahuddin and Jalalpure, 2010). Literature survey indicates that there is no scientific evidence to support the antidiabetic effect of $A$. boonei. Therefore, the present study is undertaken to investigate acute toxicity of $A$. boonei ethanol leaf extract and the effects of $A$. boonei ethanol leaf extract on the kidney markers and lipid peroxidation of diabetic rats. In severe diabetic conditions, the kidneys lose their ability to remove wastes 


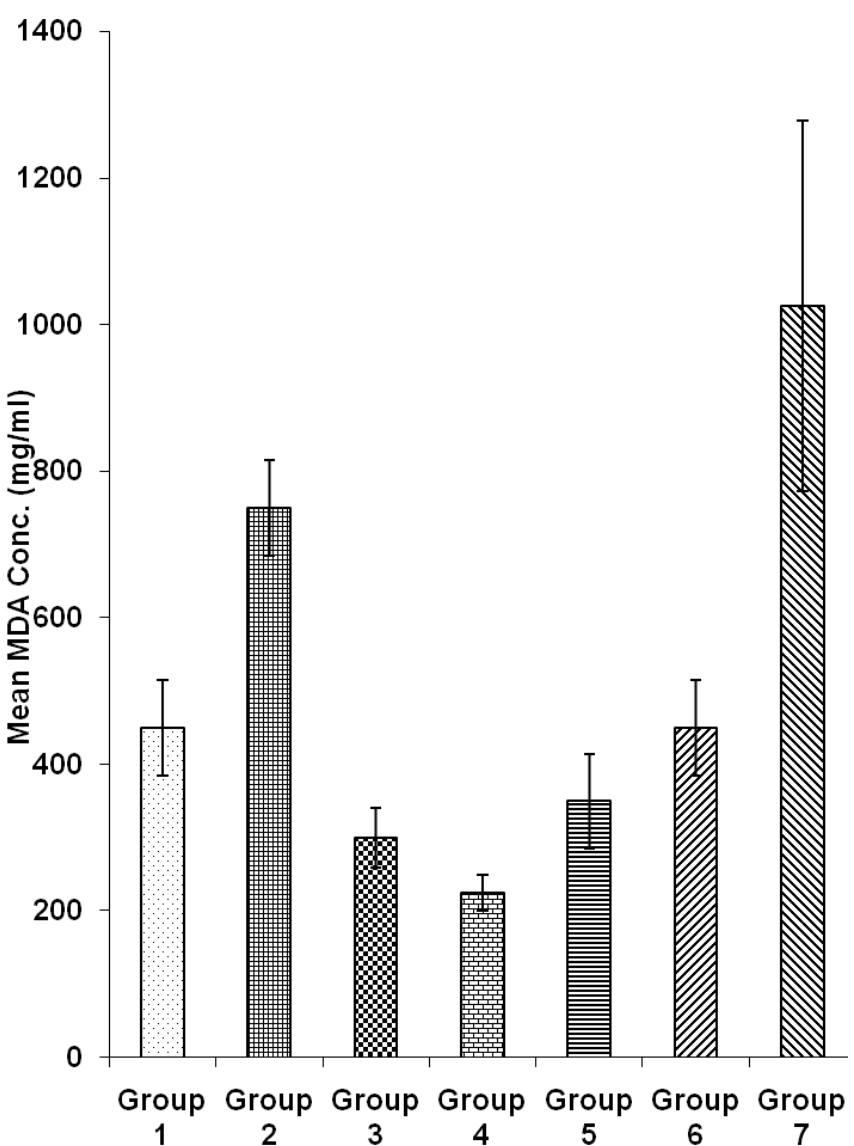

Figure 4. Effect of Ethanol leaf extract of Alstonia boonei on the malondialdehyde concentration on normal and diabetic rats.

products, such as creatinine and urea, from the blood. From the result of the acute toxicity test of the ethanol extract of $A$. boonei leaves in mice, none of the mice died in any of the groups administered 10, 100, 1000, 1900, 2600 and $5000 \mathrm{mg} / \mathrm{kg} \mathrm{b.w.} \mathrm{of} \mathrm{the} \mathrm{extract} \mathrm{after} 24 \mathrm{~h}$. Consequently, it could be suggested that the ethanol extract of $A$. boonei leaves could be generally regarded as safe (GRAS) (Lorke, 1984). However, further studies are needed to ascertain the effects of prolonged feeding of high doses of the extract on the organs and tissues of experimental animals.

It was also observed that the extract had no reparatory effect on urea and creatinine excretion by the kidney in the diabetic animals since there was no significant difference $(p>0.05)$ in the urea concentration of the treated diabetic animals compared with the diabetic control. Interestingly, the MDA concentration of the 200 and 400 $\mathrm{mg} / \mathrm{kg} \mathrm{b.w.} \mathrm{treated} \mathrm{diabetic} \mathrm{rats} \mathrm{showed} \mathrm{a} \mathrm{significant}$ decrease $(p<0.05)$ compared with the untreated diabetic rats. There was no observed significant difference $(p>0.05)$ in MDA concentration of the treated diabetic rats compared with the standard control. This shows that the extract was able to prevent lipid peroxidation by reducing the action of the alloxan-induced free radicals. Consequently, the ethanol concentration of $A$. boonei leaves has a potential antioxidant activity which can be a possible mechanism of its antidiabetic action. The flavonoids (antioxidants and free radical scavengers) in this plant may contribute to the effect of the plant extract in reducing MDA concentration and concomitant lipid peroxidetion (Afolabi et al., 2007). The capacity of flavonoids to act as antioxidants depends on their molecular structure. The position of hydroxyl groups and other features in the chemical structure of flavonoids are important for their antioxidant and free radical scavenging activities. Quercetin, the most abundant dietary flavonol, is a potent antioxidant because it has all the right structural features for free radical scavenging activity (Frei, 2006).

\section{Conclusion}

In conclusion, the ethanol leaf extract of $A$. boonei has been shown to prevent lipid peroxidation and at the same time had no reparatory effects on the kidney markers. This prevention of lipid peroxidation could be the reason ethanol extracts of $A$. boonei leaf have been used in numerous ethnomedicinal practices in combating ailments.

\section{REFERENCES}

Adonu CC, Ugwu OPC, Bawa A, Ossai EC, Nwaka AC (2013). Intrinsic Blood Coagulation Studies in Patients Suffering From Both Diabetes and Hypertension. Int. J. Pharma Med. Biol. Sci. 2 (2): 36-47.

Afolabi C, Akinmoladun EO, lbuku Emmanuel Afor, Akinrinlola BL, Onibon TR, Akinboboye AO, Obuotor EM, Farombi EO (2007). Chemical constituents and antioxidant activity of Alstonia boonei. Afr. J. Biotechnol. 6 (10):1197-1201

Andrew NC, Peter UN, Onyechi O, Ugwu OPC, Ossai EC, Chigor VN (2013). Effect of Soyabean Diet on the Serum Immunoglobulin Profile and Cd4+ Count of Male Diabetic Rats Challenged With K.Pneumoniae. Int. J. Pharm. Biol. Sci. 3 (1): 563-573.

Bello IS, Oduola T, Adeosun OG, Omisore NOA, Raheem GO, Ademosun AA (2009). Evaluation of antimalarial activity of various fractions of Morinda lucinda leaf extract and Alstonia boonei stem bark. Glob. J. Pharmocol. 3(3): 163-165.

Draper HH, Hadley M (1990). A review of recent studies on the metabolism of exogenous and endogenous malondialdehyde. Xenobiotika 20(9): 901-907.

Frei B (2006). Consumption of flavonoid-rich food and increased plasma antioxidant capacity in humans. Free Radic. Biol. Med. 35(6): 12371238.

Hazuda HP, Knap JA, Stern MP (1999). Genetic and Environmental Determinants of Type II Diabetes in Mexian Americans. Diabetic Care 14(7):649-54.

Lorke D (1984). A new approach to practical acute toxicity testing. Arch. Toxicol. 53: 275-287.

Olajide OA, Awe SO, Makinde JM, Ekhelar AI, Olusola A, Morebise O, Okpako DT (2000). Studies on the anti-inflammatory, antipyretic and analgesic properties of Alstonia boonei stem bark. J. Ethnopharmacol. 71(1-2): 179-186.

Rother KI (2007). Diabetes Treatment Bridging the Divide. N. Engl. J. Med. 356 (150): 1499-1501.

Sidiyasa K (1998). Taxonomy, phylogeny, and wood anatomy of Alstonia (Apocynaceae). International Association of Plant Taxonomy 24(2): 16-23.

Sky GM (2000). Kinetics of insulin secretion underlying notabolism events in diabetes mellitus. Diabetes mellitus: A fundamental and clinical text. Lippicott willians and Wilkins, Plucadelphia. pp. 2-11.

Tietz NW (1994). Textbook of Clinical Chemistry. $2^{\text {nd }}$ Edn. Burtis CA, Ashwood ER, W.B. Saunders Company, Philadelphia. p. 751. 